\title{
Deficiency of Protein C Inhibitor in Combined Factor V/VIII Deficiency Disease
}

\author{
Richard A. MARLAR and John H. Griffin, Department of Molecular Immunology, \\ Research Institute of Scripps Clinic, La Jolla, California 92037
}

\begin{abstract}
A B S T R A C T Activated protein C is an anticoagulant plasma protease enzyme that inactivates Factors $\mathrm{V}$ and VIII in plasma. Normal plasma contains a protein that inhibits activated protein $\mathrm{C}$ and that is distinct from previously described plasma protease inhibitors. Protein C inhibitory activity is not detectable in plasmas from four unrelated patients with combined Factor V/VIII deficiency but is present in normal amounts in plasmas from patients with simple Factor $\mathrm{V}$ deficiency or Factor VIII deficiency. It is suggested that the molecular basis for combined Factor V/VIII deficiency that exhibits simple autosomal recessive inheritance is a deficiency of protein $\mathrm{C}$ inhibitor.
\end{abstract}

\section{INTRODUCTION}

Protein $\mathrm{C}$ is a serine protease zymogen that has been isolated from bovine (1-3) and human plasma $(4,5)$. Activated protein $\mathrm{C}$ is a potent anticoagulant that shows remarkable species specificity $(3,4,6,7)$ and it is identical to autoprothrombin II-A $(7,8)$. Purified activated bovine protein $C$ inactivates purified bovine Factor Va (9-11) and Factor VIII:C (12) and it destroys Factor $\mathrm{Xa}$ binding sites and prothrombinase activities of washed bovine platelets $(13,14)$. When human activated protein $C$ is added to human plasma, it selectively inactivates Factors V and VIII (5).

Because plasma proteases are usually regulated by plasma protease inhibitors, we sought to identify the existence of an inhibitor for activated protein $\mathrm{C}$. Once we found that normal plasma inhibited activated protein $\mathrm{C}$, we theorized that patients lacking this inhibitor might present with an apparent deficiency of

Dr. Marlar is the recipient of fellowships from the American Heart Association and the National Institutes of Health. Dr. Griffin, to whom reprint requests should be addressed, is recipient of a National Institutes of Health Research Career Development Award (National Heart, Lung, and Blood Institute-00192).

Received for publication 26 August 1980. both Factor V and Factor VIII:C, since activated protein $\mathrm{C}$ readily destroys both these factors in plasma (5). Indeed, a very rare form of hemophilia in which patients are deficient in both Factors V and VIII: $C$ has been known for 26 yr $(15,16)$. Reviews of available literature indicate that this disorder shows autosomal recessive inheritance and that it is not a combination of isolated Factor V deficiency with Factor VIII:C deficiency (17-19). This report demonstrates the presence in normal plasma of a protein inhibitor of activated protein $\mathrm{C}$ that is deficient in plasma from patients with combined Factor V/VIII deficiency.

\section{METHODS}

All chemicals from commercial sources were the best grade available. DEAE-Sepharose A-50, cyanogen bromide-activated Sepharose 4B, and Sepharose 4B were products of Pharmacia Fine Chemicals, Inc., Piscataway, N. J. Dextran sulfateSepharose was made according to Kisiel (4). Purified $\alpha$ thrombin, that was prepared from purified human prothrombin using Echis carinatus venom (20), was coupled to cyanogen bromide-activated Sepharose 4B following the manufacturer's instructions. Trypsin-agarose was obtained from Pierce Chemical Co., Rockford, Ill. The chromogenic substrate, S-2238, Phe-Pip-Arg-paranitroanilide, was purchased from Kabi AG, Stockholm, Sweden. Heparin $(5,000 \mathrm{U} / \mathrm{ml})$ was obtained from Organon Inc., West Orange, N. J. Antisera to human $\alpha_{1}$-antitrypsin, $\alpha_{2}$-antichymotrypsin, $\overline{\mathrm{Cl}}$-inhibitor, antithrombin III, $\alpha_{2}$-macroglobulin, and plasminogen were obtained from Calbiochem-Behring Corp., American Hoechst Corp., San Diego, Calif. Anti- $\alpha_{1}$-antiplasmin was obtained from Nordic Immunology, Tilberg, Holland. Human plasma was obtained from healthy normal donors and anticoagulated (1:10) with $3.8 \%$ sodium citrate. The human plasma pool was a mixture of plasma from 15 normal donors. Five Factor VIII:C-deficient plasmas and one Factor V-deficient plasma were purchased from George King Biomedical, Overland, Kans. One Factor V-deficient plasma was a gift from Dr. Douglas Triplett. The combined Factor V/VIII-deficient plasmas were generously provided by Dr. Roger Edson who sent plasmas from two unrelated patients, Dr. Fred Dombrose and his colleagues, and Doctors Robert Rosenberg and M. Bern. Factor VIII concentrate (Hemophil) and Factor IX concentrate (Proplex) were gifts from Hyland Therapeutics Div., Travenol Laboratories, Inc., Costa Mesa, Calif. 
Human protein $\mathrm{C}$ was purified from commercial Factor IX concentrate (Proplex). The first step in the procedure employed DEAE-Sephadex chromatography with salt gradient elution as described. ${ }^{1}$ Fractions containing thrombin-activated anticoagulant and protein $\mathrm{C}$ antigenic activities were pooled and subjected to chromatography on dextran sulfate-Sepharose as described by Kisiel (4). The fractions from this column that contained protein $C$ were pooled and subjected to preparative polyacrylamide gel electrophoresis as described elsewhere for the purification of Factor X. ${ }^{1}$ Purified protein $\mathbf{C}$ appeared greater than $95 \%$ homogenous on polyacrylamide gels in the presence of sodium dodecyl sulfate and reducing agent and the protein elicited a monospecific antiserum upon injection into a goat.

Protein $C$ was activated by $\alpha$-thrombin-Sepharose. $200 \mu l$ of thrombin-Sepharose that had been washed exhaustively with Tris-buffered saline, $0.01 \mathrm{M}$ Tris- $\mathrm{Cl}, 0.15 \mathrm{M} \mathrm{NaCl}, \mathrm{pH} 7.4$, was added to $3 \mathrm{ml}$ of protein $\mathrm{C}(29 \mu \mathrm{g} / \mathrm{ml})$ in Tris-buffered saline. The activation of protein $\mathrm{C}$ was followed by the appearance of hydrolytic activity against the chromogenic substrate, S-2238. In the spectrophotometric assay, $60 \mu \mathrm{l}$ of the sample was added to $600 \mu \mathrm{l}$ of $0.1 \mathrm{mM} \mathrm{S}-2238$ in $0.05 \mathrm{M}$ Tris-Cl, $0.1 \mathrm{M} \mathrm{NaCl}, \mathrm{pH}$ 8.3. The increase in $\mathrm{A}_{405} / \mathrm{min}$ was determined using a Gilford recording spectrophotometer. Maximal activity was observed within $60 \mathrm{~min}$, at which time the thrombin-Sepharose was removed by centrifugation. Activated protein $\mathrm{C}$ was stored in frozen aliquots at $-70^{\circ} \mathrm{C}$ and it retained full activity for at least 6 mo.

Activated protein $\mathrm{C}$ inhibitory activity in plasma was assayed by measuring the ability of plasma to inhibit the amidolytic activity of the enzyme against S-2238 $(4,5)$. In the assay, $150 \mu \mathrm{l}$ of plasma, $100 \mu \mathrm{l}$ of activated protein $\mathrm{C}(1$ $\mu \mathrm{g} / \mathrm{ml}), 50 \mu \mathrm{l}$ of heparin $(35 \mathrm{U} / \mathrm{ml}$ final concentration), and $50 \mu \mathrm{l}$ of anti-prekallikrein gamma globulin (21) were incubated at $37^{\circ} \mathrm{C}$. At various times a $60-\mu \mathrm{l}$ aliquot was removed, mixed with $600 \mu \mathrm{l}$ of S-2238 and assayed for hydrolysis of the substrate. The heparin and anti-prekallikrein antibodies were found useful in reducing the background amidolytic activities of plasma proteases.

To determine if the inhibitor of activated protein $\mathrm{C}$ was a protein, $400 \mu$ l of trypsin-Sepharose was incubated with $1 \mathrm{ml}$ of partially purified inhibitor that was obtained by dialyzing fractions obtained from chromatography of plasma on DEAESephadex A-50 (22). For this trypsinisation, all reactants were in Tris-buffered saline. The reaction proceded for $2 \mathrm{~h}$ at $37^{\circ} \mathrm{C}$ and then trypsin-Sepharose was removed by centrifugation. Aliquots of activated protein $\mathrm{C}$ were then incubated with inhibitor aliquots that were either exposed or unexposed to trypsin-Sepharose. After $30 \mathrm{~min}$ at $37^{\circ} \mathrm{C}$, the residual activated protein $\mathrm{C}$ activity was determined using the $\mathrm{S}-2238$ hydrolysis assay.

Plasma (3 liters) was fractionated on DEAE-Sephadex A-50 $\left(14 \times 50 \mathrm{~cm}\right.$ column) at $20^{\circ} \mathrm{C}$ with elution by an increasing salt, decreasing $\mathrm{pH}$ gradient as previously described (22). 2-ml aliquots from various column fractions were dialyzed against Tris-buffered saline overnight at $4^{\circ} \mathrm{C}$ and assayed for inhibitory activity against activated protein $\mathrm{C}$. The elution positions of known plasma protease inhibitors were determined using double immunodiffusion analysis with commercial antisera. The elution positions of $\alpha_{2}$-macroglobulin, $\overline{\mathrm{Cl}}$-inhibitor, antithrombin III, and $\alpha_{1}$-antiplasmin were independently verified by the fact that each of these inhibitors has been purified in our laboratory from pools of fractions from similar columns. $^{2}$

\footnotetext{
${ }^{1}$ Marlar, R. A., A. J. Kleiss, and J. H. Griffin. Reevaluation of the extrinsic system of blood coagulation. Submitted for publication.

2 Griffin, Kleiss, and Miles. Unpublished observation.
}

\section{RESULTS}

Inhibition of activated protein $C$ by normal and deficient plasmas. The inhibition of activated protein $\mathrm{C}$ by normal and various deficient plasmas was studied by preincubating the enzyme with samples of plasma before measuring the amidolytic activity of the enzyme against the tripeptide substrate, S-2238. Six individual normal plasmas as well as two different pools of normal plasmas inhibited activated protein $\mathrm{C}$ in similar timedependent reactions (Fig. 1A). Activated protein $\mathrm{C}$ activity was reduced to $0-25 \%$ of its original value within $30 \mathrm{~min}$. However, activated protein $\mathrm{C}$ was not inhibited by four combined Factor V/VIII-deficient plasmas from four unrelated patients (Fig. 1A); even after 30 min no detectable $( \pm 10 \%)$ inhibition occurred. The ability of Factor V-deficient plasmas and Factor VIII-deficient plasmas to inhibit activated protein $\mathrm{C}$ was indistinguishable from that of normal plasma (Fig. 1B). Thus, the absence of inhibitory activity was unique to the plasmas from patients with inherited combined Factor V/VIII deficiency.

In preliminary experiments, the presence of calcium ions and phospholipid either alone or together had no

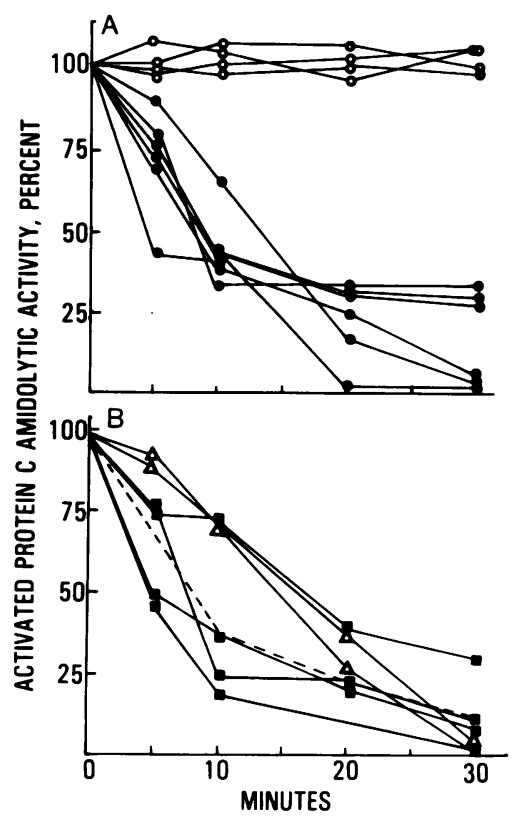

FIGURE I Inactivation of activated protein $\mathrm{C}$ by normal and various deficient plasmas. Activated protein $C$ was incubated with plasma and aliquots of the reaction mixture were assayed at various times for residual enzymatic activity. Assay conditions are described in Methods. (A) Percent of activated protein $\mathrm{C}$ activity remaining after incubation of the enzyme with different individual normal plasmas $(\bullet)$ or with different individual combined Factor V/VIII-deficient plasmas (O) from four unrelated patients. (B) Percent of activated protein $\mathrm{C}$ activity remaining after incubation with different Factor VIII-deficient plasmas ( $\square$ ) and two different Factor V-deficient plasmas $(\triangle)$. 
significant effect on the inhibitory activity of normal plasma.

To determine if anything in the combined Factor V/VIII-deficient plasmas might adversely affect the normal protein $\mathrm{C}$ inhibitor, normal plasma was diluted with Factor V/VIII-deficient plasma or with buffer before assaying the inhibition of activated protein $\mathrm{C}$. The results (Fig. 2) show that nothing in the combined Factor V/VIII-deficient plasma altered the ability of normal plasma to neutralize activated protein $\mathrm{C}$. Between 0 and $8 \%$ normal plasma, a linear dose-response relationship was observed in the inhibition assay (Fig. 2 ). This establishes a quantitative assay for the inhibition of activated protein $\mathrm{C}$ and the data indicate that $\sim 12 \%$ normal plasma $(150 \mu \mathrm{l})$ neutralizes $100 \mu \mathrm{l}$ of $1 \mu \mathrm{g} / \mathrm{ml}$ of activated protein C. Moreover, since the assay is sensitive to $2 \%$ normal plasma, the observation of no detectable inhibition $( \pm 10 \%)$ by the combined Factor V/VIII-deficient plasmas after $30 \mathrm{~min}$ (Fig. 1A) implies there is $<2 \%$ of the inhibitor in the patient's plasma.

Commercial Factor VIII concentrate and Factor IX concentrate from one manufacturer were assayed for their ability to inhibit activated protein C. Neither one contained detectable inhibitory activity. In other assays, the supernatant of barium-adsorbed plasma was found to contain a normal level of the inhibitor of activated protein $\mathrm{C}$.

Fractionation of protein $C$ inhibitor on DEAESephadex. To define some of the properties of the protein $\mathrm{C}$ inhibitor, normal plasma was fractionated on DEAE-Sephadex. One major region of activity that inhibited activated protein $\mathrm{C}$ was found. The inhibitor activity eluted at the beginning of the gradient just behind the bulk of gamma globulins but before any beta globulins such as plasminogen or Factor XII. The known plasma protease inhibitors, $\alpha_{1}$-antitrypsin, $\alpha_{1^{-}}$

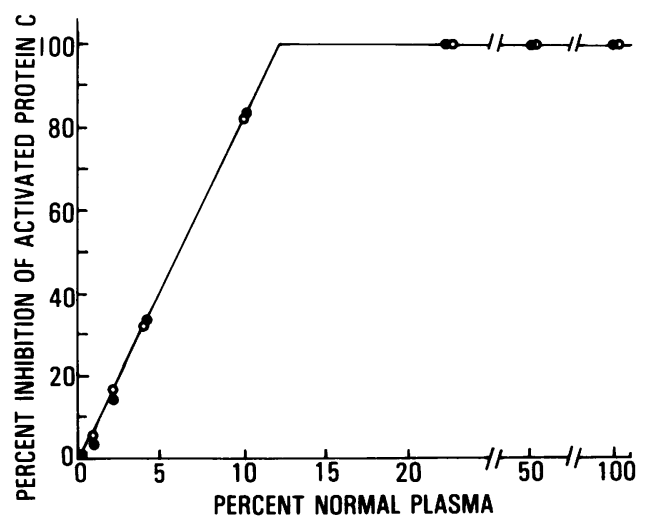

FIGURE 2 Inhibition of activated protein $C(1 \mu \mathrm{g} / \mathrm{ml})$ by different dilutions of normal plasma in $30 \mathrm{~min}$ at $37^{\circ} \mathrm{C}$. Normal plasma was diluted with either Tris-buffered saline $(O)$ or with Factor V/VIII-deficient plasma (O) before its addition to the inhibitor assay as described in Methods. antichymotrypsin, $\alpha_{2}$-macroglobulin, $\overline{\mathrm{Cl}}$-inhibitor, antithrombin III, and $\alpha_{1}$-antiplasmin, were eluted much later than the inhibitor of activated protein $C$. No overlap of the protein $\mathrm{C}$ inhibitor activity and the known plasma inhibitors was seen. Moreover, assays of the fractions from the DEAE-Sephadex column showed that activated protein $\mathrm{C}$ was not inhibited by any of the known plasma inhibitors.

To determine if the protein $\mathrm{C}$ inhibitory activity was protein in nature, trypsin-Sepharose was assessed for its ability to destroy the inhibitory activity of partially purified inhibitor. Partially purified inhibitor was obtained by dialyzing a pool of fractions obtained from a DEAE-Sephadex column. The inhibitory activity was not lost from the pool of activity during dialysis implying that the inhibitor is a macromolecule. Exposure of the partially purified inhibitor to trypsinSepharose destroyed $81 \%$ of the inhibitor activity. In controls, the inhibitor incubated with buffer lost none $( \pm 10 \%)$ of its activity. Thus, it appears that the inhibitor of activated protein $\mathrm{C}$ is a protein because it is not dialyzable and is destroyed by trypsin.

\section{DISCUSSION}

The results of this study show that normal plasma contains an inhibitor of activated protein C. This inhibitor elutes from DEAE-Sephadex at low ionic strength at $\mathrm{pH} 8.4$ just after most gamma globulins and it is entirely separated from all known plasma protease inhibitors on this column. The protein $\mathrm{C}$ inhibitor is present in barium-absorbed plasma but not in commercial Factor VIII or Factor IX concentrates that were tested. The inhibitor is destroyed by trypsin and is not dialyzable; therefore, it is presumed to be a protein. Its plasma concentration is such that $18 \%$ normal plasma neutralizes approximately an equal volume containing $1 \mu \mathrm{g} / \mathrm{ml}$ of activated protein C.

Because activated protein $\mathrm{C}$ selectively and potently destroys Factors V and VIII:C in plasma (5), we hypothesized that a deficiency of the inhibitor of activated protein $\mathrm{C}$ would result in decreased levels of Factors V and VIII:C. Therefore, we tested plasmas from four unrelated patients with inherited combined Factor V/VIII deficiency. None of these plasmas inhibited activated protein $\mathrm{C}$, even upon prolonged incubation with the enzyme. Mixing patient plasma with dilutions of normal plasma showed no influence of patient plasma on the inhibitor present in normal plasma. Based on a standard dilution curve, each patient plasma has no detectable $(\leqslant 2 \%)$ protein $\mathrm{C}$ inhibitor activity.

The combined Factor V/VIII deficiency disease usually exhibits simple autosomal recessive inheritance (17-19) and patients' plasmas are reported to contain a normal level of Factor V and Factor VIII antigens $(19,23,24)$. No measure of Factor VIII:C antigen 
has been reported. Factor $\mathrm{V}$ and Factor VIII:C coagulant activities are usually between 5 and $30 \%$ $(15-19,24)$. The genetics of this disorder have been particularly puzzling since Factor VIII:C deficiency is a sex-linked trait whereas Factor $\mathrm{V}$ deficiency shows autosomal recessive inheritance. Moreover, except for one case, simple Factor V deficiency or Factor VIII:C deficiency has not been found in the parents or relatives of patients with combined Factor V/VIII deficiency (15-19). The fact that patient's plasma lacks the protein C inhibitor and that activated protein $\mathrm{C}$ destroys Factors V and VIII:C leads to the first reasonable hypothesis for the molecular basis for inherited combined Factor V/VIII disease. We suggest that protein $\mathrm{C}$ inhibitor is a hitherto undescribed protein that is inherited in an autosomal recessive manner. Combined Factor V/VIIIdeficient patients lack this protein. A total deficiency of this protein allows activated protein $C$ to escape normal physiological regulation. This results in excessive ongoing destruction of Factors V and VIII:C such that their coagulant activity levels are reduced but their antigenic levels may or may not be reduced. It follows from this hypothesis that therapy, whenever required, for patients with inherited combined Factor V/VIII disorder should include a source of protein $\mathrm{C}$ inhibitor such as fresh plasma.

\section{ACKNOWLEDGMENTS}

The authors are very grateful to Doctors R. Edson (University of Minnesota), F. Dombrose (University of North Carolina), and M. Bern and R. Rosenberg (Harvard Medical School) for providing patient plasma samples. Helpful discussions with Doctors T. Zimmerman, D. Triplett, and R. Rosenberg are gratefully acknowledged. The authors thank Alice Kleiss for skillful technical assistance in the preparation of purified protein $\mathrm{C}$.

This work was supported in part by research grants from the National Institutes of Health, National Heart, Lung, and Blood Institute-24891, and from the California chapter of the American Heart Association.

\section{REFERENCES}

1. Stenflo, J. 1976. A new vitamin-K dependent protein. Purification from bovine plasma and preliminary characterization. J. Biol. Chem. 251: 355-363.

2. Esmon, C. T., J. Stenflo, J. W. Suttie, and C. M. Jackson. 1976. A new vitamin K dependent protein. A phospholipid-binding zymogen of a serine esterase. J. Biol. Chem. 251: 3052-3056.

3. Kisiel, W., L. H. Ericsson, and E. W. Davie. 1976. Proteolytic activation of protein $\mathrm{C}$ from bovine plasma. Biochemistry. 15: 4893-4900.

4. Kisiel, W. 1979. Human Protein C. Isolation, characterization, and mechanism of activation by $\alpha$-thrombin. J. Clin. Invest. 64: 761-769.

5. Marlar, R. A., A. Kleiss, and J. H. Griffin. 1980. Modes of anticoagulant action of human protein $\mathrm{C}$, a vitamin $\mathrm{K}$ dependent serine protease. Fed. Proc. 39: 544.

6. Marciniak, E. 1972. Inhibitor of human blood coagulation elicited by thrombin.J. Lab. Clin. Med. 79: 924-934.

7. Murano, G., W. H. Seegers, and R. Zoltan. 1974. Auto- prothrombin II-A: A competitive inhibitor of autoprothrombin C (Factor Xa). A review with additions. Thromb. Diath. Haemorrh. Suppl. 57: 305-314.

8. Seegers, W. H., E. Novoa, R. Henry, and H. Hassouna. 1976. Relationship of "new" vitamin K dependent protein C and "old" autoprothrombin II-A. Thromb. Res. 8: 543-553.

9. Kisiel, W., W. Canfield, L. Ericsson, and E. W. Davie. 1977. Anticoagulant properties of bovine plasma protein C following activation by thrombin. Biochemistry. 16: 5824-5831.

10. Esmon, C., P. Comp, and F. Walker. 1980. Functions for protein C. In Vitamin $\mathrm{K}$ Metabolism and Vitamin $\mathrm{K}$ Dependent Proteins. J. W. Suttie, editor. University Park Press, Baltimore. 72-83.

11. Canfield, W., M. Neshiem, W. Kisiel, and K. Mann. 1978. Proteolytic inactivation of bovine Factor Va by bovine activated protein C. Circulation. 57-58(Suppl. II): 210.

12. Vehar, G., and E. W. Davie. 1980. Preparation and properties of bovine Factor VIII (antihemophilic factor). Biochemistry. 19: 401-410.

13. Comp, P., and C. Esmon. 1979. Activated protein C inhibits platelet prothrombin-converting activity. Blood. 54: $1272-1281$.

14. Dahlbäck, B., and J. Stenflo. 1980. Inhibitory effect of activated protein $\mathrm{C}$ on activation of prothrombin by platelet-bound Factor Xa. Eur. J. Biochem. 107: 331-335.

15. Oeri, J., M. Mattler, H. Isenschmid, F. Hauser, and F. Koller. 1954. Angeborener Mangel an Faktor V (parahaemophilie) verbunden mit Echter Hemophilie A bei zwei Brudern. Mod. Probl. Paediatr. 1: 575-588.

16. Iversen, T., and P. Bastrup-Madsen. 1956. Congenital familial deficiency of Factor V (parahemophilia) combined with deficiency of antihaemophilic globulin. $\mathrm{Br}$. J. Haematol. 2: 265-275.

17. Seligson, U., and B. Ramot. 1969. Combined Factor V and Factor VIII deficiency: report of four cases. Br. J. Haematol. 16: 475-486.

18. Smit-Sibinga, C., J. Gokemeyer, L. ten Kate, and F. Bosvan Zwol. 1972. Combined deficiency of Factor $V$ and Factor VIII: Report of a family and genetic analysis. Br. J. Haematol. 23: 467-481.

19. Cimo, P., J. Moake, M. Gonzalez, E. Natelson, and K. Fox. 1977. Inherited combined deficiency of Factor $V$ and Factor VIII: report of a case with normal Factor VIII antigen and ristocetin-induced platelet aggregation. Am. J. Hematol. 2: 385-391.

20. Morita, T., S. Iwanaga, and T. Suzuki. 1976. The mechanism of activation of bovine prothrombin by an activator isolated from Echis carinatus venom and characterization of the new active intermediates. J. Biochem. (Tokyo). 79: $1089-1108$.

21. Bouma, B. N., L. A. Miles, G. Beretta, and J. H. Griffin. 1980. Human plasma prekallikrein. Studies of its activation by activated Factor XII and of its inactivation by diisopropyl phosphofluorodate. Biochemistry. 19: 11511160.

22. Griffin, J. H., and C. G. Cochrane. 1976. Human Factor XII. Methods Enzymol. 45: 56-63.

23. Zimmerman, T. S., O. D. Ratnoff, and A. Powell. 1971. Immunologic differentiation of classic hemophilia (Factor VIII deficiency) and von Willebrand's disease with observations on combined deficiencies of antihemophilic factor and proaccelerin (Factor V) and on an acquired circulating anticoagulant against antihemophilic factor. J. Clin. Invest. 50: 244-254.

24. Giddings, J., U. Seligson, and A. Bloom. 1977. Immunological studies in combined Factor $\mathrm{V}$ and Factor VIII deficiency. Br. J. Haematol. 37: 257-264. 